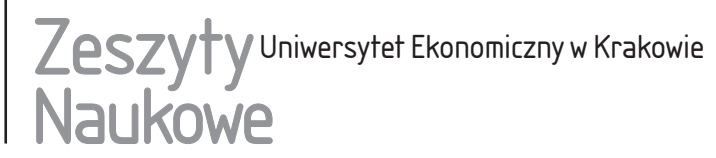

\title{
Społeczna odpowiedzialność biznesu - sprzeczności, nadużycie etyczne, znaczenie idei
}

\section{Streszczenie}

W artykule stawiam tezę, że CSR nie jest pozytywną ideą zmierzającą ku lepszej przyszłości, zrównoważonemu rozwojowi i sustainable economy, lecz narzędziem walki o prawo do kierowania korporacją, upolitycznieniem gospodarki oraz kamuflażem dla działań niemających na celu wzniosłych ideałów etycznych, lecz zysk finansowy. Przedstawiam argumenty na rzecz tezy, że CSR - rozumiany jako ideologia wykorzystywana przez zarządy korporacji - przyczynił się do kryzysu ładu korporacyjnego. Stało się tak dlatego, że CSR jako strategia czy model zarządzania ukształtował określone relacje pomiędzy właścicielami a akcjonariuszami, które przyczyniły się do słabości nadzoru właścicielskiego. Tekst przeciwstawia się zbyt łatwej idealizacji idei CSR, nadużyciom etycznym (m.in. pokusie nadużycia i zjawisku bailoutu) oraz niespójności teoretycznej w ramach tzw. kapitalizmu kantowskiego. Analizowane przykłady uwypuklają fakt nieponoszenia przez kadry kierownicze odpowiedzialności za nadużycia i błędy, co - warto podkreślić - jest sprzeczne z hasłem społecznej odpowiedzialności biznesu. Deficyt idei CSR został zasygnalizowany przez skonfrontowanie modelu kapitalizmu kantowskiego - czyli teorii interesariuszy Roberta E. Freemana - z modelem kapitalizmu własnościowego Miltona Friedmana.

Słowa kluczowe: CSR, etyka biznesu, kapitalizm kantowski, teoria interesariuszy, Robert E. Freeman, Milton Friedman, Immanuel Kant, imperatyw kategoryczny.

Katarzyna Guczalska, Uniwersytet Ekonomiczny w Krakowie, Katedra Filozofii, 31-510 Kraków, ul. Rakowicka 27, e-mail:k.guczalska@gmail.com 


\section{Krytyka CSR}

Artykuł jest krytyką społecznej odpowiedzialności biznesu - corporate social responsibility (CSR), rozumianej jako ideologia menedżerska służąca osłabieniu mechanizmów nadzoru właścicielskiego ${ }^{1}$. Tekst przedstawia nadużycia teoretyczne i etyczne, które należy łączyć z rozwojem doktryny CSR. W tekście zestawione zostały dwa paradygmaty myślenia o gospodarce: kapitalizm kantowski związany z Robertem E. Freemanem oraz kapitalizm właścicielski (wolnościowy) $-\mathrm{z}$ Miltonem Friedmanem ${ }^{2}$. Zebrane argumenty przeciwstawiają się tezie, która zdaje się dominować w dyskursie dotyczącym CSR: koncepcja Friedmana ma oznaczać brak odpowiedzialności (etyki) w biznesie, a szereg różnych sloganów i definicji CSR - obecność odpowiedzialności (etyki) w biznesie.

\section{Etyka?}

R. Freeman głosi konieczność „kreowania przyszłości” przez menedżerów i brania pod uwagę korzyści interesariuszy - w interesie firmy [Freeman 1983, s. 10]. Ponieważ w środowisku społecznym wzrosło znaczenie takich grup jak konsumenci, ekolodzy, związki zawodowe czy media, w procesie zarządzania należy brać pod uwagę zysk podmiotów innych niż tylko właściciele firmy. Działania podejmowane przez firmę mające na celu pożytek interesariuszy nie są jednak wdrażaniem w życie określonego modelu etyki:

Przedstawione analizy można bardzo łatwo błędnie zinterpretować jako jeszcze jedno wołanie o społeczną odpowiedzialność lub etykę biznesu. Podczas gdy te kwestie są ważne same w sobie, poziom strategii przedsiębiorczej to inne pojęcie [Freeman 1984, s. 107].

W zarządzaniu interesariuszami R. Freeman poszukuje „środków realizacji przez firmę wcześniej założonych celów (maksymalizacji zysku)" [Wicks, Gilbert i Freeman 1994, s. 476].

We wczesnej teorii interesariuszy chodzi o skuteczne zarządzanie, przetrwanie firmy na rynku oraz jej długofalową strategię, a nie etykę [Charan i Freeman 1980, s. 11]. Interesariusze są podporządkowani realizacji celów biznesowych. Nie ma tu mowy o traktowaniu interesariuszy jako celów samych

${ }^{1}$ Problematykę tę podejmowali: M.C. Jensen, K. Goodpaster, E. Sternberg, A.K. Sundaram, A.C. Inkpen [Sundaram i Inkpen 2004a, b].

${ }^{2}$ M. Friedman, pisząc tekst The Social Responsibility of Business Is to Increase Its Profits, nie znał doktryny kapitalizmu kantowskiego. Niniejszy artykuł nie broni neoliberalizmu (ideę wolnego rynku można rozumieć na wiele sposobów), lecz jedynie konfrontuje CSR z poglądami Friedmana. 
w sobie - w sensie kantowskim. Używając języka R. Freemana z okresu „kapitalizmu kantowskiego", można powiedzieć, że wczesny Freeman traktuje udziałowców zewnętrznych w sposób instrumentalny.

\section{Etyka Kanta}

Zarządzający firmą menedżerowie dbają o zysk finansowy, a jednocześnie cel ten próbują pogodzić z działaniami prospołecznymi. Jeśli cele właścicieli i kadry kierowniczej są zgodne, realizacja projektu Freemana jest harmonijna i godna wsparcia. Co jednak zrobić, gdy właściciele określą strategiczne cele firmy w inny sposób niż jej kierownictwo [Friedman 1999, s. 261]? Kto w przypadku rozbieżnych decyzji ma rację moralną [Jensen 2001]? Czy wbrew woli właścicieli zysk może nie zostać uznany za priorytetowy cel firmy i może być przekazany (rękami menedżerów) na rzecz wspólnoty interesariuszy? Argumentem na „tak” ma być imperatyw kategoryczny Immanuela Kanta. Kadra zarządzająca firmą ma moralny obowiązek brania pod uwagę korzyści wszystkich interesariuszy - w przeciwnym wypadku będą oni traktowani jak środki do celu przez dążących do zysku właścicieli.

Akceptacja egoizmu właścicieli jako motywu działań gospodarczych prowadzi do nieetycznego traktowania innych podmiotów. Etyka Kanta ma obligować pracodawcę, aby ten - pod ciężarem racji etycznej - godził się na możliwość, by zatrudnione przez niego osoby działały niezgodnie z jego wolą i interesem.

\section{Błędne racje}

Odwołanie się do etyki Kanta jako argumentu na rzecz zastąpienia firmy działającej dla interesu właścicieli interesem wszystkich zainteresowanych podmiotów jest chybione. Po pierwsze: czy kapitalizm właścicielski oznacza traktowanie innych jako środków do celu w sensie kantowskim? A jeśli oznacza to w jakimkolwiek sensie, to czy tego rodzaju traktowanie może zniknąć w jakimkolwiek innym kapitalizmie, w którym wypracowywany jest zysk? Wydaje się, że nie. Gdy kupuję coś od kogoś, to w pewnym (słabym) sensie traktuję go jako środek do celu: do zaspokojenia mojej potrzeby. W takim ujęciu traktowanie innych jako środków do celu nie może całkowicie zniknąć. Czy istnieje więc jakiś inny, mocniejszy, sens „traktowania innych jako środka do celu”, który jest obecny w kapitalizmie właścicielskim, a kapitalizmie kantowskim - nie? Wydaje się, że nie. 
Zasada nieinstrumentalnego traktowania podmiotów została w kapitalizmie kantowskim naruszona. Słuszne jest przekonanie, że rozporządzanie własnością może być sprzeczne z prawami innych. Podobnie jednak prawa innych mogą stać w sprzeczności z prawem do decydowania o własności - zależy, do którego aspektu przywiążemy większą wagę. Jeśli menedżerowie bądź grupa interesariuszy naruszają dobro właścicieli ze względu na wspólne interesy, to właściciele są traktowani jako środki do celu. Imperatyw kategoryczny jest zasadą dotyczącą wszystkich ludzi. Bez idealistycznego założenia zgodności celów wszystkich zainteresowanych działalnością firmy podmiotów teoria interesariuszy jest wewnętrznie sprzeczna ${ }^{3}$.

M. Friedman negował doktrynę CSR z powodu braku zabezpieczenia interesu właścicieli przed arbitralną decyzją osób zarządzających firmą. Czy uzasadnienie nowego ładu korporacyjnego dopuszczającego decyzję menedżera sprzeczną z wolą właściciela da się obronić stanowiskiem Kanta w kwestii własności? Wydaje się, że nie. Filozof wiąże własność prywatną z wolnością jednostki oraz zobowiązaniem do nieingerowania w cudzą własność bez wyraźnego pozwolenia właściciela: „Zaprowadź taki stan, w którym własność każdego człowieka może być zabezpieczona przed każdym innym" [Kant 2006, s. 49].

Umowa społeczna w ujęciu Kanta zawierana jest w celu ochrony, a nie ograniczania prawa własności. Są to wszystko punkty zbieżne ze stanowiskiem M. Friedmana i sytuują poglądy Kanta po stronie tradycji liberalnej [Szymaniec 2009, s. 45; Kant 2006, s. 79]. Pogwałcenie prawa własności jest odebraniem wolności i wyrządzaniem krzywdy [Kant 2006, s. 59]. Do poglądów Kanta powinno się odwoływać w celu - paradoksalnie - podważenia zasad kapitalizmu kantowskiego, a nie jego obrony.

W ramach tradycji liberalnej podział czy ograniczenie własności są możliwe, jednak jako gest dobrowolny, a nie jako część systemu (ładu) korporacyjnego i z góry narzuconej formy organizacji gospodarowania. Zastosowanie etyki Kanta jest chybione jako próba osłabienia mechanizmów nadzoru właścicielskiego ${ }^{4}$.

\footnotetext{
${ }^{3}$ Rzadko zwraca się uwagę, że udziałowcy zewnętrzni mogą traktować właścicieli w sposób instrumentalny, natomiast często i chętnie wspomina się o tym, że jest dokładnie na odwrót. Kluczowy w krytyce omawianej teorii wydaje się jednak argument ,z wolności”, zob. dalsza część wywodu oraz punkt 5 niniejszego artykułu.

${ }^{4}$ Teorię można próbować oprzeć na innych fundamentach (myśl Arystotelesa, J. Rawlsa, prawa człowieka, feminizm itd.).
} 


\section{Istota sprawy: wolność}

I. Kant nie nakazuje, by traktować człowieka jedynie jako cel, a nigdy jako środek. Jeśli powiemy: „,spełniaj nie tylko te zobowiązania w stosunku do interesariuszy, które podejmuje się ze względu na interes firmy czy własny, ale zawsze spełniaj też wszelkie inne zobowiązania moralne względem nich, wynikające z tego, że każdy interesariusz jest osobą i powinien być potraktowany zawsze zarazem jako cel, a nie tylko jako środek", to należy jednocześnie zapytać: w jakim sensie spełnianie różnych zobowiązań moralnych wobec interesariuszy jest sprzeczne ze stanowiskiem M. Friedmana? Przecież jeśli właściciel firmy tego pragnie i tak zadecyduje, to może spełniać wszelkie zobowiązania etyczne wobec interesariuszy, jakie tylko przyjdą mu do głowy - byleby spełniał je zgodnie z wolnym wyborem, „,na własny koszt”, nie obarczał nimi (dotyczy to również zobowiązań finansowych) innych podmiotów, chodząc przy tym w glorii chwały bycia podmiotem etycznym (a dokładnie taką sytuację mamy w kapitalizmie kantowskim, w odniesieniu do kadry zarządzającej). Zapytajmy również: co mogą oznaczać różne zobowiązania moralne, które właściciel może mieć w stosunku do interesariuszy? Jeśli jest to na przykład postulat dotrzymywania umów, to czy Friedman (czy jakikolwiek liberał lub neoliberał) opowiadał się za niedotrzymywaniem umów? A jeśli byłby to postulat „bycia uczciwym biznesmenem w stosunku do wszystkich uczestników gry rynkowej”, to czy Friedman opowiadał się za tym, by człowiek działał w przestrzeni gospodarczej w sposób nieuczciwy?

Oto sedno krytyki: kapitalizm kantowski nie odnosi się do filozofii Kanta jako takiej, lecz jest rażąco powierzchowną i wyjętą z całego kontekstu filozofii Kanta reinterpretacją jednej z formuł imperatywu kategorycznego. Co więcej, stanowisko Kanta jest stanowiskiem liberalnym. Obowiązki, aby były moralne, muszą być przyjęte dobrowolnie. Narzucone mogą być tylko obowiązki prawne ${ }^{5}$. Zdaniem Kanta zakres legitymowanej działalności państwa w zakresie stanowienia prawa jest wyznaczony celem umowy społecznej. Oznacza to, że państwo nie może ingerować w życie obywateli w większym stopniu, niż to jest potrzebne ${ }^{6}$. Chodzi o to, by wolność danej jednostki mogła współistnieć w społeczeństwie obywatelskim z taką samą co do zasady wolnością innych. Najogólniej można powiedzieć, że w myśli Kanta liberała system prawny ma zabezpieczać

${ }^{5}$ Czy CSR ma stać się obowiązkiem prawnym? Wdrożenie przepisów dotyczących CSR i tzw. obowiązku raportowania pozafinansowego ma „wejść w życie nie później niż 6 grudnia 2016 r. i powinno mieć zastosowanie po raz pierwszy od 1 stycznia 2017 r." [Firmy będa musiały... 2016].

${ }^{6}$ Dlaczego Freeman nie rozwija wątku filozofii społecznej Kanta, skoro jest ona ściśle związana z etyką? Dlaczego wyrywa z całej filozofii Kanta jedną kwestię? 
maksymalną wolność jednostki, która daje się pogodzić z wolnością innych i nie przeradza się w samowolę, która mogłaby prowadzić do rozpadu społeczeństwa.

I. Kant nie miał złudzeń co do tego, że ludzie są egoistyczni ${ }^{7}$. Chodziło mu jednak o to, by ich przekonać, że nie powinni traktować innych wyłącznie jako środka do swoich celów, lecz aby traktowali innych również - oprócz tego, że są oni wykorzystywani jako środki - w charakterze celów samych w sobie. Kant pragnął zatem przekonać, że nie powinniśmy postrzegać innych wyłącznie instrumentalnie. W sferze prawa obowiązek ten wyraża się głównie w zakazie niewolnictwa (bardzo istotna dla filozofa kwestia) oraz nakazie, by stosunki prywatnoprawne oparte były na prawdziwej dobrowolności, pojmowanej jako wolność od przymusu. Tylko tyle, a może - w kontekście teorii interesariuszy - aż tyle... Kantowi bynajmniej nie chodziło o to, o co chodzi w „kapitalizmie kantowskim”. Przedsiębiorca jest wolnym człowiekiem $\mathrm{i}$ - jako wolny podmiot - sam rozważa, które zobowiązania powinien wypełnić, albowiem - zgodnie z pierwszą formułą imperatywu kategorycznego - każdy musi sam zdecydować, które zobowiązania są dlań tak istotne, że ich wypełnianie powinno stać się powszechnym prawem. Rzecz tylko w tym, by przedsiębiorca - jak zresztą każdy inny człowiek - nie traktował innych ludzi jedynie jako środki do własnych celów, nie uprzedmiotowił ich, tak jak w starożytności pan uprzedmiotawiał niewolnika ${ }^{8}$.

\section{Kuriozum teoretyczne}

W kapitalizmie kantowskim etyka Kanta jest traktowana w sposób wybiórczy, powierzchowny i instrumentalny. Amerykańscy teoretycy biznesu zajmują się filozofią na potrzeby biznesu i pragmatyzmu gospodarczego. Czy refleksja R. Freemana jest wyrazem jakiejś szerszej i poważnej egzegezy pism Kanta? Nie. Dyskusja o etyce firmy toczy się tu w obszarze teorii zarządzania, a nie na polu pogłębionej refleksji filozoficznej. Fakt, że udało się Freemanowi upowszechnić teorię interesariuszy jako wykładnię stanowiska Kanta, kładzie się cieniem na środowisku etyków biznesu, którzy zaakceptowali teorię niespójną, jedną z wielu teorii zarządzania - dziedziny niepretendującej do bycia głębszą filozofią, czy nawet etyką - jako wyraz wzorcowej (etycznej) idei w dziedzinie gospodarki ${ }^{9}$.

${ }^{7}$ Filozof pisze na przykład: ,zz drewna tak krzywego jak to, z którego jest zrobiony człowiek, nie da się wystrugać nic prostego" [Kant 2005, s. 36].

${ }^{8}$ Człowiek nie jest instrumentum vocale (mówiącym narzędziem) czy „żywym narzędziem”, jak wyrażał się Arystoteles.

${ }^{9} \mathrm{CSR}$ cieszy się więcej niż dużą popularnością, a wysyp literatury na temat teorii interesariuszy jest ogromny. Można zaryzykować tezę, że w przeważającej części publikacji zakłada się jako oczywistość, że CSR pojawia się w kontekście etyki Kanta. Rzecz jasna, wskazuje się na konkretne ogra- 
Warto również w tym miejscu zgłosić pewien postulat, ten mianowicie, by mylące określenie „kapitalizm kantowski” zastąpić formułą „kapitalizm Freemanowski” - ta bowiem nazwa w adekwatny i precyzyjny sposób oddaje rangę i miejsce koncepcji interesariuszy w ramach teorii zarządzania.

I. Kant postuluje etykę opartą na bezinteresowności. Skutki czynów są dla intencji opartej na obowiązku moralnym nieistotne [Kant 2001, s. 19]. Korzyść ekonomiczna i instrumentalizacja ludzi - również właścicieli - wyklucza etykę. Postulowane w kapitalizmie kantowskim „służenie” [Evan i Freeman 1999, s. 275] jako narzędzie koordynowania interesów interesariuszy jest zajęciem stanowiska utylitaryzmu w etyce, gdyż mówi o korzyści zainteresowanych działaniem firmy podmiotów. Nie można jednak teorii nazywać kapitalizmem kantowskim, a jednocześnie mówić o zysku interesariuszy. Te dwa modele etyki są sprzeczne. Niestety, istotny dla Kanta oraz w obszarze refleksji etycznej problem niewspółmierności opłacalności (korzyści) z etyką nie jest na gruncie teorii zarządzania wyraziście stawiany jako problem, a wręcz jest zacierany [Freeman, Harrison i Cavalcanti Sá de Abreu 2015]. Z kolei sama teoria interesariuszy jawi się współcześnie jako panaceum, jako hybryda obecna już we wszelkich możliwych kontekstach (np. [Freeman, Wicks i Gilbert 1994]).

Kapitalizm kantowski jest pod wieloma względami koncepcją kuriozalną ${ }^{10}$. Mamy tu do czynienia ze sprzecznościami na wielu poziomach. Istotną antynomię stanowi pomieszanie trzech stadiów rozwoju teorii interesariuszy, którym odpowiadają różne ujęcia roli interesariuszy oraz odmienne koncepcje zarządzania firmą ${ }^{11}$. W konflikt wchodzi ze sobą zwłaszcza - mówiący o skutecznym zarządzaniu firmą - wczesny model interesariuszy ${ }^{12} \mathrm{z}$ kapitalizmem kantowskim

niczenia tej etyki w kontekście teorii interesariuszy [Nowak 2015, s. 178] czy zauważa się, że „rozważanie CSR jako przejawu realizacji imperatywu kategorycznego napotyka na istotne utrudnienia" [Tapek 2016, s. 14]. Problem jest jednak głębszy i dotyczy samej (rzekomo filozoficznej) podbudowy koncepcji. Zarówno forma, której użył Freeman do zaprezentowania swojego stanowiska (wybiórczość, powierzchowność, instrumentalne podejście do myśli Kanta), jak i jego treść (fundamentalna niespójność stanowiska Kanta z teorią interesariszy) każą odrzucić dokonany przez Freemana zabieg ugruntowania swojej teorii na skojarzeniu go z refleksją Kanta. Innymi słowy: teoria interesariuszy nie posiada filozoficzno-etycznej podbudowy, którą można określić mianem kantyzmu.

${ }^{10}$ Nawiązanie do etyki Kanta nie stanowiłoby nadużycia teoretycznego, gdyby ograniczyło się do kwestii sprawiedliwej płacy czy partnerskiej relacji z pracownikami. Teoria interesariuszy idzie dalej: zmienia całościowy ład korporacyjny, rangę i funkcję właścicieli w firmie.

${ }^{11}$ Teorię interesariuszy można rozumieć jako model zarządzania skoncentrowany na wpływie otoczenia na firmę; jako koncepcję wypełniania obowiązków etycznych opartego na imperatywie kategorycznym Kanta, jak również jako ideę o charakterze pragmatycznym, w ramach której roszczenia interesariuszy są powiązane z kondycją finansową firmy. Wgląd w rozwój idei - zob. [Freeman i McVea 2016].

${ }^{12}$ R. Freeman głosi, że koncepcja ta nie ma nic wspólnego z etyką - zob. punkt 2 niniejszego artykułu. 
- kładący nacisk na etykę. Wydaje się, że z powodu tej właśnie niezgodności Freeman w 1994 r. wycofał się z obrony kapitalizmu kantowskiego na rzecz pragmatystycznego rozumienia tej teorii [Stanny 2015]. Czy dzięki temu zabiegowi koherencja całościowej teorii została ocalona? Jeśli na postawione pytanie odpowiemy twierdząco, to spoistość analizowanej koncepcji jest osiągnięta za cenę ogólnikowego i nieprecyzyjnego jej ujęcia, w ramach którego należałoby umniejszyć czy zbagatelizować wątki etyczne. Spójność konceptu Freemana jest de facto bardzo kłopotliwa dla propagatorów teorii interesariuszy jako sposobu na uetycznienie biznesu. Ostatecznie bowiem sednem poglądów Freemana okazuje się skuteczne zarządzanie - a nie bezinteresowna etyka (Kanta).

Zwrot w poglądach Freemana stanowi teoretyczne wyzwanie dla zwolenników uznania kapitalizmu kantowskiego za podstawę etyki firmy. Koncepcja ta jest $\mathrm{w}$ istocie pozbawiona sensu i uzasadnienia, o ile jest refleksją o praktykach CSR w oderwaniu od finansów i sukcesu firmy - a tak właśnie konsekwentny etyczny zwolennik CSR musi myśleć.

\section{Nadużycia etyczne}

\subsection{Egoizm, oportunizm, hipokryzja}

CSR jest koncepcją tworzoną i popularyzowaną przez środowiska menedżerskie, które dzięki niej czerpią dla siebie określone profity [Frederick 1987, s. 142-161]. Egoizm skryty w teorii interesariuszy jest gorszy niż egoizm ,tradycyjny", ponieważ skrywa się pod hasłami etycznymi. Kapitalizmowi właścicielskiemu zarzuca się, że w zasadzie odpowiedzialności kadry kierowniczej wobec właścicieli skrywa się egoizm, gdyż reguła ta nie daje wystarczających korzyści innym podmiotom. Na obiekcję tę można odpowiedzieć, że kapitalizm kantowski służy z kolei egoizmowi menedżerów (oraz innych interesariuszy). Daleko od prawdy odbiega sugestia, że właściciele są egoistami i nie chcą się dzielić, a skaza ta nie dotyka kadry kierowniczej. Nie tylko nie dostrzega się groźby nadużyć ze strony kadry kierowniczej, lecz wręcz w naiwny sposób się ją idealizuje ${ }^{13}$. Teoria interesariuszy, skupiona na kadrze menedżerskiej, ma być otwarta na dobro wspólne, poszerzając grono osób, o które się dba czy którym wręcz się służy ${ }^{14}$. Zupełnie przemilcza się sytuację, w której kadra kierow-

${ }^{13}$ Grupa kierownicza posiada „mądrość Salomonową”, „,troszczy się o zdrowy rozwój korporacji”, ,utrzymuje zrównoważone stosunki między udziałowcami zewnętrznymi” itp. [Evan i Freeman 1999].

${ }^{14}$ Aby wyrobić sobie zdanie o bezinteresownej „służbie” menedżerów, wystarczy prześledzić, jak zachowują się przedstawiciele kadry kierowniczej oraz instytucje skupiające menedżerów, gdy próbuje się ograniczyć ich zarobki. Chodzi o reakcje na różne sposoby wzmocnienia nadzoru 
nicza zawęża troskę o dobro wspólne - choć nie jest trudno znaleźć przykłady potwierdzające taką sytuację. Można wskazać na zarządy spółek, które przyczyniły się do szeregu nieprawidłowości i strat finansowych, a nie ponosiły z tego powodu większej odpowiedzialności ${ }^{15}$. W literaturze przedmiotu zauważono zjawisko pomijania lub nietraktowania poważnie kwestii oportunizmu menedżerskiego [Boatright 2009, s. 485]. Freeman przyznał w końcu, że oportunizm kadry kierowniczej jest problemem, jednocześnie jednak bagatelizował tę istotną kwestię [Phillips, Freeman i Wicks 2003, s. 483].

M. Friedman promuje klarowną zasadę etyczną ,czynienia dobra na własny koszt" [Friedman 1999, s. 263]. Z zasadą tą w sprzeczności stoi teoria interesariuszy, którą cechuje duża hipokryzja w odniesieniu do działań menedżerów ${ }^{16}$. W ramach projektów CSR-owych kadra kierownicza korporacji nie ponosi kosztów czynienia dobra. Jeśli istnieją menedżerowie, którzy angażują się społecznie i (po pracy) wydają na inicjatywy prospołeczne własne pieniądze - to wypełniają postulat etyczny Friedmana, a nie Freemana. Jeśli z kolei tak nie czynią (a teoria interesariuszy wcale do tego nie zachęca), to koszt CSR obciąża właścicieli firmy, a nie kadry kierownicze. I tu paradoks: w teorii interesariuszy fundujący dobro właściciele przedstawieni są jako egoiści, zaś w roli dobroczyńców występują idealizowani menedżerowie, którzy dobra na własny koszt nie czynią.

\subsection{Rozproszenie odpowiedzialności}

W teorii interesariuszy można widzieć ideologię menedżerską, która stosowana jest przez kadrę kierowniczą w celu osłabienia mechanizmów ładu korporacyjnego [Key 1999, s. 317-328]. Ta metoda zarządzania wiąże się z unikaniem odpowiedzialności przez zarząd firmy. Elaine Sternberg potępia zjawisko, które nazywa rozproszeniem odpowiedzialności w biznesie, czy wręcz jej anihilacją [Sternberg 1997, s. 5]. Rozproszenie to ma źródło w zrównaniu wszystkich interesariuszy w ich prawach wobec korporacji. Zrównanie to powoduje zastąpienie „mierzalnych standardów wyników finansowych” realizacją prywatnych celów:

Część najgłośniejszych zwolenników teorii interesariuszy to właśnie osoby, które najbardziej mogą zyskać na unikaniu odpowiedzialności: członkowie kierownictwa przedsiębiorstw. Zastępując niejasnym pojęciem „równoważenia interesów” mierzalny standard wyników finansowych, teoria stron zainteresowanych daje

właścicielskiego, które proponowane są przez opinię publiczną, czy o stosunek do różnego rodzaju inicjatyw płynących ze strony akcjonariuszy (m.in. Shareholder Bill of Rights).

${ }^{15}$ Dopiero ujawnienie nadużyć wywołało dyskusję, czy premie dla menedżerów są dopuszczalne w sytuacji, w której spółka generuje straty dla właścicieli, cena akcji spada, a podatnicy dofinansowują ją w ramach bailoutu.

${ }^{16}$ O uwikłaniu w hipokryzję działań filantropijnych korporacji - zob. [la Cour i Kromann 2011]. 
członkom kierownictw przedsiębiorstw wolność dążenia do celów osobistych

[Sternberg 1998, s. 70].

\subsection{Pokusa nadużycia}

Celem kapitalizmu kantowskiego jest „ożywienie” kapitalizmu menedżerskiego [Evan i Freeman 1999, s. 267]. Główną cechą tego rodzaju kapitalizmu jest rozdzielenie funkcji posiadania (właściciele) od funkcji zarządzania (menedżerowie) ${ }^{17}$. Czy ożywienie (wzmocnienie) tendencji do rozdzielania funkcji posiadania i zarządzania prowadzi do wzrostu postaw etycznych i odpowiedzialności za swoje czyny? Wydaje się, że nie. W kapitalizmie własnościowym przedsiębiorca dąży do zysku, jednak nie za wszelką cenę, gdyż ryzykuje swoim majątkiem i może stracić wszystko. Nie podejmuje zbyt ryzykownych inwestycji, ponieważ są one dla niego zbyt dotkliwe. Nadmierna chciwość tamowana jest samoistnie, gdyż mechanizm ograniczenia pokusy nadużycia wbudowany jest immanentnie w samą strukturę kapitalizmu własnościowego. Tymczasem osoba zarządzająca współczesną korporacją - w sytuacji rozdzielenia własności i posiadania - nie ponosi bolesnych konsekwencji swoich ryzykownych działań. Chociaż bowiem wynagrodzenie kadry kierowniczej zależy od dobrego zarządzenia firmą, to jednak w sytuacji złego zarządzania skutki uderzają raczej we właścicieli. Tak działo się choćby podczas kryzysu finansowego, w którym poszkodowane były głównie instytucje i ich akcjonariusze, a nie ich zarządy [Kirkpatrick 2009, s. 13-14]. Gdy bankrutował Lehman Brothers, poszkodowanymi byli właściciele akcji, których cena spadła o ponad $90 \%$ w ciągu kilku miesięcy. W tym samym czasie wielu menedżerów otrzymywało wysokie premie.

Pokusę nadużycia (moral hazard) definiuje się jako sytuację, w której podmiot chroniony przed ryzykiem zachowuje się inaczej, niż gdyby w pełni mu podlegał. Taką sytuację mamy we współczesnej korporacji, w której - w sytuacji rozdzielenia posiadania i zarządzania - menedżer może wiele zyskać, kiedy ryzykownie inwestuje, a jednocześnie niewiele straci, jeśli jego inwestycje się nie powiodą. Zarządy współczesnych spółek mogą podejmować ryzykowne decyzje za cudze pieniądze (należące do właścicieli). Niestety, w kapitalizmie kantowskim pokusa nadużycia nie napotyka na żadną barierę [Stanny 2010, s. 146-147] - jest wręcz przeciwnie: powierniczość kadry kierowniczej wobec wszystkich interesariuszy osłabia nadzór właścicielski. Prowadzi to do niemożności hamowania dążenia do osiągania nadmiernego zysku przez menedżerów.

${ }^{17}$ Chodzi o przeniesienie władzy z właścicieli na osoby zarządzające firmą [Domańska 1986]. W sytuacji rozproszonego właścicielstwa kadry kierownicze zarządzające firmą nie są poddane ścisłej kontroli. Problem ten pojawia się zwłaszcza w Stanach Zjednoczonych, gdzie własność akcjonariuszy jest bardzo rozproszona i akcjonariat nie ma dużego wpływu na nadzorowanie menedżerów. 
W modelu kapitalizmu opartego na własności prywatnej ryzykowne inwestycje są ograniczane samoczynnie dzięki związaniu zarządzania z posiadaniem. Zerwanie tej łączności jest od dawna krytykowane w tradycji liberalnej. Na temat ten pisał Ludwig von Mises [2007, s. 264] czy Adam Smith ${ }^{18}$.

\subsection{Skandal etyczny?}

W dobie kryzysu finansowego, za którego początek uznaje się bankructwo banku Lehman Brothers w 2008 r., zarządy wielkich korporacji liczyły na możliwość zrzeczenia się odpowiedzialności za negatywne skutki swoich ryzykownych działań, korzystając z możliwości obciążenia społeczeństwa kosztami złego zarządzania firmą. Pozwoliło to kadrom kierowniczym na podejmowanie coraz bardziej ryzykownych działań na rynku finansowym ${ }^{19}$.

Kryzys zwrócił uwagę na problem zbyt hojnego wynagradzania kadry kierowniczej w instytucjach finansowych. W latach 2008-2009 politycy decydowali o wspaniałomyślnym i kosztownym ratowaniu prywatnych firm z pieniędzy podatników. W Stanach Zjednoczonych pieniądze dostały m.in. takie podmioty jak Goldman Sachs, AIG, General Motors. Podobnie było w wielu krajach europejskich (we Francji, w Niemczech, Wielkiej Brytanii czy Irlandii). Przeciwnicy zjawiska bailoutu (pomocy finansowej rządu z pieniędzy podatników) twierdzą, że zaburza ono mechanizmy wolnorynkowe: wolną konkurencję, etykę pracy, odpowiedzialność za swoje czyny, prowadzi do upolitycznienia gospodarki. Zwolennicy akcentują dobro wspólne: nie można dopuścić do chaosu w społeczeństwie, ludzie nie mogą stracić pracy, w sytuacjach kryzysowych ludzie muszą sobie pomagać, politycy ponoszą odpowiedzialność za sferę gospodarki itd. ${ }^{20}$ Fakt, że zjawisko bailoutu ma miejsce, świadczy o dalekim upolitycznieniu gospodarki oraz przyzwoleniu społecznym na takie zachowania. Skąd bierze się ta akceptacja ${ }^{21}$ ? Jest przecież czymś głęboko niemoralnym i sprzecznym z ideą sprawiedli-

${ }^{18}$ A. Smith twierdził, że spółkom akcyjnym szkodzi rozdział zarządzania i posiadania, gdyż interesy prowadzi się wtedy „niedbale i rozrzutnie” [Chancellor 2001, s. 184].

${ }^{19}$ Jedną z nielicznych instytucji, która odmawiała ponoszenia kosztów działań przez podatnika, był Deutsche Bank. Menedżerowie znanego koncernu AIG do końca prowadzili ryzykowne strategie finansowe, licząc na pomoc państwa i zwycięstwo odpowiedzialności wspólnotowej - nad indywidualną.

${ }^{20}$ Zgodę na interwencjonizm państwa tak tłumaczy F. Bastiat: ,,[...] posunięcia protekcjonistyczne przynoszą wielkie korzyści niewielkiej liczbie beneficjentów i przynoszą wielkiej liczbie konsumentów niewielkie straty. W tych warunkach łatwo jest wprowadzić w życie protekcjonistyczne posunięcia" [Bastiat 2003, s. 9].

${ }^{21}$ Konflikt „,interesu społeczeństwa” z wolnym rynkiem jest znakiem rozpoznawczym „społecznej odpowiedzialności organizacji”, która ,przejawia się w poszukiwaniu sposobów generowania zysków w ramach obowiązującego prawa, a interesy społeczeństwa powinny być zabezpieczane 
wości, aby ktoś płacił pieniądze za błędy innych osób. Jest czymś niemoralnym, aby osoby źle wykonujące swoją pracę dostawały za nią horrendalne wynagrodzenia. Jak nazwać sytuację, w której za błędy indywidualnych menedżerów i ich brak odpowiedzialności płaci społeczeństwo? Skandal etyczny?

W systemie wolnej gospodarki źle pracujący menedżerowie nie mogliby dostać wysokich premii i odpraw, źle zarządzane przedsiębiorstwo by upadło, a nie zostało wsparte pieniędzmi podatników. Nie są to tezy gołosłowne. Friedman w latach 70. dezaprobował program ratowania przed upadłością firmy Chrysler [Friedman 1997, s. 141-142]. Krytykował fakt, że politycy w sposób krótkowzroczny wydają pieniądze podatników na ratowanie upadającej firmy (jak się potem okazało, również Forda i General Motors), a nie zarządzają gospodarką, mając na względzie jej długookresowy interes. Co jest bowiem istotą etyki biznesu? Dobro człowieka, oparte na gospodarce niesterowanej rękami polityków ${ }^{22}$. Teoria interesariuszy nie wsparła Friedmana w tym aspekcie ${ }^{23}$. CSR stał się jednym z elementów polityki państwa opiekuńczego [Albareda, Lozano i Ysa 2007, s. 391-407]. Uetycznienie sfery biznesu objawiło się jako zastąpienie odpowiedzialności kadry kierowniczej wobec właścicieli prymatem celów społecznych, które wspiera państwo.

Sytuacja, w której politycy w nadmierny i interesowny sposób sterują gospodarką, prowadzi do wyparcia formy kapitalizmu własnościowego i zastąpienia go kapitalizmem kumoterskim, w którym „firmy zwiększają swoje zyski dzięki przysługom rządu, a w zamian wspierają polityków, którzy te przysługi wyświadczają. Taka relacja to kumoterstwo" [Holcombe 2014].

Wolność gospodarowania zastępowana jest „kapitalizmem kolesiów”24, czyli dyktatem rozmaitych grup interesu powiązanych ze światem polityki ${ }^{25}$. Tymczasem sfera polityki i sfera biznesu powinny być oddzielone, nacisk powinien być położony na prawo (nie znajomości), które wyznacza uczciwe reguły

za sprawą regulacji prawnych i procesu politycznego, nie zaś praw wolnego rynku" [Żelazna-Blicharz 2013, s. 18].

${ }^{22}$ Ingerencja polityczna jest widoczna w spółkach skarbu państwa, w których prezesi (z partyjnego nadania) zmieniają się wraz z kolejnymi wyborami. Widać tu ciekawą analogię w odniesieniu do CSR: systemowe (polityczne) wymuszanie decyzji wbrew interesom akcjonariuszy. „Prywatni posiadacze akcji nigdy nie mogą być pewni, czy minister skarbu nie zmusi zarządu spółki do działań sprzecznych z jej interesem, a tym samym interesem akcjonariuszy” [Gadomski 2015].

${ }^{23}$ CSR jest ściśle związany z państwem opiekuńczym [Brejning 2012]. Zob. opis roli rządu w promowaniu CSR we Włoszech, w Norwegii i Wielkiej Brytanii [Albareda i in. 2008, s. 347-363].

${ }^{24}$ Inne terminy to: crony capitalism, korporacjonizm, merkantylizm, socjalizm, kapitalizm: polityczny, kantowski, kumoterski, kreatywny (jak kreatywna księgowość).

${ }^{25}$ M. Friedman nazwał CSR socjalizmem w najczystszej postaci. Był wrogiem socjalizmu, jednak nie państwa oraz ingerencji państwa w gospodarkę (nie był anarchistą). Ingerencja państwa w procesy gospodarcze może przybierać różne formy. 
prowadzenia biznesu, zaś dobro wspólne nie powinno być realizowane kosztem zanegowania odpowiedzialności indywidualnej.

\subsection{Fuzje i przejęcia}

Źródłem rozwoju fenomenu CSR nie jest refleksja etyczna, lecz zjawiska takie jak kapitalizm menedżerski, procesy globalizacyjne oraz procesy fuzji i przejęć [Hendry 2001]. CSR może służyć jako narzędzie ograniczające formy współpracy między firmami. Jeśli dochodzi do fuzji czy przejęcia, menedżerowie zarządzający firmą mogą stracić pracę ${ }^{26}$. Aby temu zapobiec, będą starali się nie dopuścić do fuzji lub przejęcia, pod hasłem społecznie odpowiedzialnego biznesu. W takim przypadku działania menedżerów są sprzeczne z interesami akcjonariuszy, ponieważ mechanizm fuzji czy przejęcia daje nadzieję na lepsze wyniki firmy. Jednakże menedżerowie firmy - zgodnie z założeniami teorii interesariuszy - „nie będą podejmowali decyzji, w których główną rolę odgrywa ocena dotycząca finansowych interesów udziałowców" [Marens i Wicks 1999, s. 281].

W kontekście ograniczania fuzji i przejęć, warto przytoczyć następującą uwagę: „Pojawiają się [...] wątpliwości etyczne dotyczące równych szans, sprawiedliwej dystrybucji i odpowiedzialności menedżerów za obowiązki należytego zarządzania przedsiębiorstwami” [Klimczak 2012, s. 199].

\section{Friedman contra Freeman}

Który kapitalizm jest bardziej etyczny - propagowany przez Friedmana czy Freemana? A może oba są jednostronne, nie wyrażają uniwersalnej etyki, lecz obrazują grę interesów w firmie? Wydaje się, że obie wizje należą do paradygmatu kapitalistycznego i składają się na jego wewnętrzną dialektykę. Oba modele akceptują własność prywatną - kapitalizm kantowski wzmacnia władzę zarządzających firmą, a kapitalizm właścicielski władzę właścicieli27. W kapitalizmie kantowskim podważone zostały tradycyjnie pojmowane cele firmy: maksymalizacja wartości dla właścicieli oraz działania menedżerów (pracowników) podejmowane $\mathrm{w}$ interesie akcjonariuszy (pracodawców). $\mathrm{Z}$ tego punktu widzenia

${ }^{26}$ Prawdopodobieństwo utraty pracy dotyczy także menedżerów dobrze zarządzających firmą, ponieważ po połączeniu firm kadry zarządzające będą się dublować.

${ }^{27}$ CSR osłabia instytucję własności prywatnej, zwłaszcza w spółkach z rozproszonym akcjonariatem. Teoria interesariuszy to wyraz konfliktu pomiędzy menedżerami a właścicielami/akcjonariuszami [Hendry 2001, s. 160-162]. 
można zaryzykować tezę, że jest to koncepcja niespójna nie tylko z filozofią Kanta, lecz z kapitalizmem jako takim ${ }^{28}$.

Z perspektywy kapitalizmu kantowskiego odpowiedzialność menedżerów wobec właścicieli jawi się jako egoizm. Za wzorzec etyki oraz optimum działania firmy uznana została korzyść wszystkich. Tymczasem „system oparty na wolnej przedsiębiorczości i własności prywatnej” zdyskredytowano jako jednowymiarowy, egoistyczny i nieetyczny. Skąd bierze się taka wykładnia? Współczesna postać demokracji to demokracja egalitarna. Deprecjacja neoliberalnego posiadania dla siebie ma służyć ideałom równości i sprawiedliwości dystrybutywnej. Współczesna etyka gospodarcza kładzie nacisk na kategorie wspólnotowe, starając się jednocześnie wyjść poza optykę stricte monetarną, matematyczne dane liczbowe i zysk ${ }^{29}$.

M. Friedman nie ma dobrej prasy wśród etyków biznesu, którzy (przeważnie) przyjęli jedną z wielu menedżerskich teorii firmy - kapitalizm kantowski - jako główny model działania przedsiębiorstwa i z tej perspektywy oceniają przestrzeń gospodarczą ${ }^{30}$. Teoria interesariuszy urosła do rangi monopolu etycznego, choć jest to tylko jedna z koncepcji, która stara się uchwycić złożoność współczesnych praktyk i norm biznesowych [Moon 2002, s. 3]. Zwolennikom kapitalizmu kantowskiego należy przypomnieć, że nie istnieje jeden model ani firmy, ani gospodarki, ani etyki. Przeciwnie, należy mówić o wadach i zaletach różnych odmian zarządzania oraz kapitalizmu - porównywać społeczne skutki rozwoju gospodarczego każdej z form, potencjał innowacyjny, sposoby dystrybucji dochodu czy zatrudnienia [Hall i Soskice 2001].

Zarówno koncepcja Freemana, jak i Friedmana ma mocne i słabe strony. Nie należy mitologizować ani ideologizować kapitalizmu kantowskiego poprzez próbę zdyskredytowania stanowiska Friedmana jako nieetycznego i uznania kantowskiego za etyczny. Z obu wzorców nie da się wyeliminować ani działań sprzecznych z prawem, ani zachowań nieetycznych. Koncepcja Friedmana niesie ze sobą określoną etykę firmy i nie neguje idei odpowiedzialnego biznesu - zarówno w sensie ekonomicznym, jak i etycznym. Ostatni kryzys pokazał natomiast, że ideologia menedżerska neguje nie tylko odpowiedzialność biznesu w sensie ekonomicznym, lecz nawet w sensie moralnym (bailout i inne nadużycia). Pogląd Friedmana stwierdzający, że dyrektor korporacji ponosi odpowiedzialność przed właścicielem firmy, jest zajęciem stanowiska zrozumiałego i etycznego ${ }^{31}$. Wątpli-

${ }^{28}$ To zależy, jak zdefiniujemy kapitalizm. Problem „kapitalizmu bez właścicieli” - zob. [Albert 1994, s. 88].

${ }^{29}$ W kontekście myśli A. Sena problem analizuje autorka, zob. [Guczalska 2014a, s. 225-250].

${ }^{30}$ Kapitalizm kantowski powinien nazywać się kapitalizmem Freemanowskim.

${ }^{31}$ Pogląd ten kwestionuje C.D. Stone [1997, s. 64]. 
wości budzi natomiast następujący fakt „ożywiony” kapitalizmem kantowskim: ryzykowne decyzje podejmują menedżerowie, a ich finansowe konsekwencje ponoszą właściciele firmy.

M. Friedman występuje przeciwko przymusowi i upolitycznieniu gospodarki, a nie etyce. Odpowiedzialny biznes polega na ,angażowaniu się w działania w celu zwiększania swoich zysków dopóty, dopóki przestrzega [się] reguł gry; to oznacza, że uczestniczy [się] w otwartej i wolnej konkurencji bez podstępów czy oszustwa" [Friedman 1999, s. 260].

Jeśli celem firmy jest zysk, nie oznacza to, że dobro innych podmiotów jest lekceważone. Troskę o dobro innych ludzi wyraził w klasycznej formie - bynajmniej nie bagatelizujący etyki - Adam Smith. Jego zdaniem jednostka, maksymalizując swój dochód, przykłada (słynną) niewidzialną rękę do wzrostu dobra wspólnego (Smith pragnie, by dochód społeczny był jak największy). Wszelkie zobowiązania moralne i wspólnotowe powinny być przyjmowane indywidualnie i dobrowolnie [Friedman 1999, s. 265] - z tego też powodu nie może istnieć jeden, obligujący wszystkich model zarządzania. Z kolei w kapitalizmie kantowskim powinności moralne są częścią systemu korporacyjnego, którego - z powodu racji moralnych - nie można odrzucić.

CSR przedstawia się jako sielankową ideę propagującą dobrowolne działania na rzecz „lepszego społeczeństwa i czystszego środowiska” (Zielona Księga). W perspektywie tak pozytywnego i ogólnikowego stwierdzenia nie znajdziemy żadnego oponenta tej teorii, ponieważ każdy chce żyć w lepszym społeczeństwie i czystszym środowisku. Jeśli jednak wdrażanie modelu zarządzania miałoby odbywać się rzeczywiście na zasadzie dobrowolności, to zwolennicy CSR kontynuują myśl Friedmana (zob. [Guczalska 2014b]). W systemie wolnorynkowym człowiek może stosować taką metodę zarządzania, jaką chce, byleby była ona zgodna z prawem i obyczajami etycznymi danego kraju. Warto przy tym pamiętać, że w sferze etyki neoliberałowie byli z reguły konserwatystami ${ }^{32}$.

Odrzucając Friedmanowskie argumenty przeciwko CSR, odrzucamy koncepcję, w której ludzie zakładają firmy po to, by zarabiać, a nie bankrutować, bezwzględnie ponoszą odpowiedzialność za swoje czyny oraz w wolny i nieprzymuszony sposób decydują o swoich społecznych zaangażowaniach. Przeciwstawienie Freemana i Friedmana nie polega na tym, że jeden opowiada się za modelem etycznym, a drugi nie. Spór Friedman contra Freeman dotyczy roli i funkcji kadry zarządzającej w nowoczesnej korporacji, która pracuje w warunkach rozdziału funkcji własności i zarządzania. Oba modele są związane z określoną etyką, natomiast ich przeciwstawność dotyczy metod zarządzania

\footnotetext{
${ }^{32}$ F. von Hayek napisał tekst Dlaczego nie jestem konserwatysta, sam był jednak bliski konserwatyzmowi w sensie wiary w długofalowy i samorzutnie wytworzony ład historyczny, przeciwstawiony ,sztucznemu” planowaniu.
} 
firmą. Jeśli jednak ktoś chce bronić wolnego rynku, własności prywatnej oraz dobrowolnych zobowiązań społecznych - powinien używać do tego innego języka niż stosowany w ramach paradygmatu neoliberalnego ${ }^{33}$. Nie sprawdził się on jako całość i nie został przyjęty jako pozytywny program etyczny, stając się wręcz symbolem wyzysku i nierówności społecznych ${ }^{34}$. Sam M. Friedman mówił zbyt mało o etyce, preferował język opisowy - do którego należy rodząca szereg nieporozumień sławetna formuła „business of business is business” (zob. [Guczalska 2014b, s. 296]).

Hasło CSR nie oznacza jedynej drogi ku etyce, sprawiedliwości i odpowiedzialności. Próba monopolizowania etyki w obrębie jednej teorii przynosi więcej szkody niż pożytku. Niestety, rzeczową dyskusję na temat CSR utrudnia fakt, że w obiegu znajdują się dziesiątki różnych definicji tego zjawiska. Są to określenia niewiele mówiące ${ }^{35}$, a ich różnorodność sprawia, że dyskusja jest utrudniona ${ }^{36}$. Polemika z koncepcją Friedmana powinna się również odbywać na bardziej pogłębionym i rzetelnym poziomie ${ }^{37}$.

\section{Znaczenie idei}

Różne ujęcia CSR powstały w oparciu o wieloznaczną koncepcję interesariuszy. Pomimo niespójności teoretycznych i nadużyć etycznych teorię tę można porównać do kuli śnieżnej, której rozrostu nie da się zatrzymać. Ani niekoherencja $\mathrm{w}$ obrębie teorii, ani ciemne interesy korporacji nie są $\mathrm{w}$ stanie podważyć nadziei wiązanych z nowym paradygmatem myślenia o ekonomii. Istnieje ogromne zapotrzebowanie na myśl włączającą biznes do rozwiązywania współczesnych problemów społecznych. Europa cierpi na kryzys ideowy. Nie można go pokonać bez wartości etycznych, które kształtują biznes i wyznaczają cele dla sprawiedliwie urządzonego społeczeństwa. Konsumpcja oraz wzrost gospodarczy nie mogą być jedynym celem rozwoju społecznego. Dobrobyt i zamożność nie mogą być jedyną miarą człowieczeństwa. Wskaźniki ekonomiczne nie mogą być ważniejsze niż ludzka godność.

${ }^{33}$ Zob. argumenty przedstawione w publikacji [Jones, Parker i ten Bos 2005, s. 97-101].

34 Jednym z konsekwentnych krytyków neoliberalizmu w Polsce jest T. Kowalik [2009].

${ }^{35}$ CSR to „takie prowadzenie biznesu, które jest ekonomicznie zyskowne, przestrzegające prawa, etyczne i społecznie wspierające" [Carroll 1983, s. 608].

${ }^{36}$ Najbardziej popularne określenia to: business ethics, corporate citizenship, sustainability bądź sustainable development, corporate environmental management, business \& society, business \& governance, business \& globalisation, stakeholder management [Visser 2005, s. 32]. W sprawie różnorodności i ewolucji definicji CSR - zob. [Carroll 1994, s. 5-29; 1999, s. 268-295].

${ }^{37}$ Przykłady błędnych interpretacji myśli Friedmana - zob. [Guczalska 2014b]. 
Zwolennikom CSR udało się wylansować dyskurs, z którego wynika, że ktoś opowiadający się za tą ideą opowiada się za etyką i odpowiedzialnością, a ktoś opowiadający się przeciwko - jest nieodpowiedzialny, gdyż kwestionuje etyczne i pożądane rozwiązania społeczne. Akcentowanie właściwej postawy etycznej w biznesie zostało powiązane z aplikacją CSR - fakt ten stał się współcześnie ważną sprawą wizerunkową i strategiczną. W XXI wieku zdajemy sobie sprawę z konieczności przemodelowania biznesu na bazie większej odpowiedzialności - w imię sprawiedliwości i dobra przyszłych pokoleń. W globalnie rozumianej idei CSR chodzi o coś więcej niż współodpowiedzialność za państwo. Chodzi o budowanie sprawiedliwego społeczeństwa, a nawet sprawiedliwości globalnej $^{38}$. CSR jest częścią szeroko rozumianej rewolucji etycznej, polegającej na przestrzeganiu praw człowieka oraz zmianie stosunku ludzi do świata przyrody $^{39}$. Bez wdrożenia tych idei pod znakiem zapytania staje dalsza egzystencja oparta na pokojowej współpracy międzyludzkiej oraz środowisku sprzyjającym dalszemu życia na Ziemi. Potrzebujemy wizji biznesu jako narzędzia postępu cywilizacyjnego, a nie źródła krzywdy, wyzysku i zanieczyszczenia przyrody. $\mathrm{Z}$ tego powodu hasło CSR stało się hasłem ważnym. Szeroko rozumiana idea (nie ideologia menedżerska) stała się jednym z elementów przesłania ideowego, które można określić mianem nowego oświecenia.

Jednym z najistotniejszych pytań, na które cywilizacja zachodnia musi sobie odpowiedzieć, jest pytanie o reguły, zgodnie z którymi biznes ma działać w społeczeństwie. Biznes wkracza do politycznej gry, ponieważ państwo opiekuńcze nie potrafi poradzić sobie ze współczesnymi wyzwaniami (imigranci, zmiany demograficzne, obciążenia socjalne). Oczekujemy od biznesu więcej zaangażowania w rozwiązywanie problemów społecznych i ochronę środowiska, ponieważ możliwości działania biznesu są dzisiaj dużo większe, potrzeby coraz bardziej rozbudowane, a politycy coraz bardziej bezradni. XXI wiek to ogrom wyzwań i potrzeb. Wydatki państwa są ograniczone, a potrzeby ludzkie - nieograniczone. Budżety międzynarodowych korporacji są niekiedy większe niż budżety państw. Idea CSR znakomicie odpowiada na potrzebę dyskursu

\footnotetext{
${ }^{38}$ Poza środowiskami teoretyków biznesu opinia publiczna nie postrzega CSR w perspektywie idei sprawiedliwości. Respondenci badania przeprowadzonego w Polsce, na Węgrzech i na Słowacji przez Bank Światowy „ogólnie rozumieją termin CSR jako oznaczający zgodność z obowiązującymi regulacjami, etycznym zachowaniem i zapewnianiem ochrony środowiska, nie uważają jednak, aby CSR był narzędziem naprawy społecznych nierówności czy był kwestią public relations" [What Does Business... 2005, s. 11].

${ }^{39}$ Czujące istoty, ludzie, zwierzęta, a nawet rośliny muszą być traktowane w sposób bardziej podmiotowy - fakt ten tłumaczy aktualność etyki Kanta. Konstatacja ta nie ma jednak nic wspólnego z osłabieniem nadzoru właścicielskiego. Nie trzeba być zwolennikiem teorii interesariuszy, żeby popierać ideę praw człowieka i ochronę przyrody.
} 
łączącego pragnienie rozwoju biznesu, przewagi konkurencyjnej firmy ze szlachetnymi celami - szacunkiem dla podmiotowości czy budową dobra wspólnego.

Czy przed biznesem stoją zadania pozagospodarcze? Jeśli biznes to coś więcej niż biznes i ma zobowiązania społeczne (a wręcz polityczne), to rodzi się obawa, którą wyraził M. Friedman: biznesmeni w sposób niedemokratyczny zyskują władzę. Jeśli bowiem spojrzeć głębiej, okazuje się, że CSR nie tyle etycznie „zmiękcza” biznes, ile umacnia obłudę. Foldery reklamowe CSR z etyką w tle stały się współcześnie zjawiskiem obligatoryjnym i masowym. Raporty CSR, obfitujące w zdjęcia bezchmurnego nieba, uśmiechniętych ludzi i bawiących się dzieci, można uznać za przykłady zorganizowanej hipokryzji [Cho i in. 2015]. Dążenie do zysku - a nie etyka - wydaje się nierzadko główną motywacją do aplikacji CSR, który służy też jako kamuflaż dla kariery zawodowej, zyskania poklasku, przetrwania firmy na rynku itp. Ten CSR-owy parawan dla prowadzenia biznesu Friedman nazwał „obłudnym mydleniem oczu” i „taktyką bliską oszustwa”.

Kapitalizm kantowski ożywił kapitalizm menedżerski, instytucję korporacji oraz powiązanie sfery biznesu i polityki. Pod przykrywką refleksji etycznej CSR dał korporacjom instrumenty ukrywania występków, sięgania po wpływy i władzę. A władza może być narzędziem budowy lub zniszczenia. Może demoralizować lub wyzwalać; oznacza rosnące aspiracje, kumulację wpływów i ekspansję nieznającą samoograniczenia. Państwo i politycy posiadają barierę - są nimi: demokracja i konstytucja. Jaką granicę posiada biznes? Prawo i etykę. Nie mamy lepszej odpowiedzi. Przesłanie do opinii publicznej jest następujące: albo egoizm ekonomiczny ma prymat nad etyką, albo etyka trzyma w ryzach egoizm ekonomiczny - w tym kadr kierowniczych korporacji, co jawnie zlekceważyła teoria interesariuszy. CSR ewoluuje jednak nadal - świadczy o tym choćby reorientacja poglądów samego R. Freemana w kierunku pragmatyzmu. W próbie uzgodnienia biznesu z pryncypiami etycznymi tkwi dalszy motor napędowy CSR - miejmy nadzieję, że w kierunku mniej zideologizowanym i egoistycznym.

\section{Podsumowanie i wnioski}

Artykuł jest krytycznym ustosunkowaniem się do idei CSR rozumianej jako ideologia menedżerska. Celem analizy jest ujawnienie niespójności teoretycznej oraz egoizmu menedżerskiego skrytego w dyskursie deklarującym „dobro interesariuszy” - a w szerszym kontekście - „,czyste środowisko” czy „lepszy świat”. Warto podkreślić, że ogólne przesłanie społecznej odpowiedzialności biznesu zawiera w sobie potencjał pozytywny (nazywam go nowym oświeceniem). Atrakcyjność proklamacji etycznych nie może jednak przesłonić dyskusyjnych założeń teorii interesariuszy, a ostatecznie - problematycznego funkcjonowania tej metody zarządzania. W tekście nie polemizuję z powierzchowną i chwytliwą 
retoryką, której wszyscy przytakną (,uczciwy handel”, „podmiotowe traktowanie”, „dobro wspólne”, „etyczny biznes”), lecz z literą tekstu R.E. Freemana oraz faktycznymi malwersacjami biznesowymi. W szczególności obnażam instrumentalizację etyki służącą doraźnym celom biznesowym oraz sposób konstruowania dyskursu dotyczącego CSR - u źródeł, jak również w perspektywie jego dalszego rozwoju. Celem artykułu jest konfrontacja dotychczasowego stanu wiedzy na temat społecznej odpowiedzialności biznesu z rzeczywistością. Co CSR deklaruje i postuluje? A jak działa i jak funkcjonuje? W przypadku teorii interesariuszy szwankuje zarówno teoria, jak i jej aplikacja.

$\mathrm{Na}$ zakończenie pragnę podkreślić trzy rzeczy. Po pierwsze, opowiadając się za zbalansowaniem idei CSR, opowiadam się za bardziej zniuansowanym i nieschematycznym podejściem do każdej idei - obojętne, czy będzie to jakaś koncepcja z zakresu etyki czy teorii zarządzania. Po drugie, w tekście została dokonana dekonstrukcja idei CSR. Tym mocniej chcę zaznaczyć, że również neoliberalizm zasługuje na podobną dekonstrukcję. Celem moich rozważań nie jest bowiem obrona neoliberalizmu, kładącego nacisk na wolny rynek, konkurencję, produkcję itd. (w gruncie rzeczy „neoliberalizm” to pojęcie nieprecyzyjne). Zarówno neoliberalizm, jak i kapitalizm menedżerski (kantowski), w swoich określonych aspektach, mogą zgodnie prowadzić do wzmocnienia etatyzmu korporacyjnego. Możliwości takiej nie można z góry odrzucić, choć udowodnienie tej tezy jest zadaniem na odrębny artykuł. Mamy współcześnie do czynienia z problemem zacieśniania się zależności pomiędzy korporacjami a światem polityki, co jest sprzeczne z myślą liberalną, która postuluje odsunięcie od siebie tych sfer. Mam wątpliwości, czy neoliberalizm realizuje wspomniany postulat liberalizmu klasycznego. Po trzecie, ani system gospodarczy (socjalistyczny czy kapitalistyczny), ani teoria zarządzania nie powinny zastępować etyki - dziedziny filozofii o niewspółmiernej pozycji kulturowej, poziomie refleksji i tradycji intelektualnej. Gospodarka nie może i nie powinna zastępować wyższych celów człowieka. Należy starać się eliminować nieprawidłowości życia gospodarczego, jednocześnie jednak iluzją jest twierdzenie, że CSR - jako zasłona dymna dla interesów kadr menedżerskich - jest etyce bliski i nadaje się do zaspokajania wyższych celów człowieka.

\section{Literatura}

Albareda L., Lozano J.M., Ysa T. [2007], Public Policies on Corporate Social Responsibility: The Role of Governments in Europe, ,Journal of Business Ethics”, nr 74.

Albareda L. i in. [2008], The Changing Role of Governments in Corporate Social Responsibility: Drivers and Responses, „Business Ethics: A European Review”, vol. 17, nr 4.

Albert M. [1994], Kapitalizm kontra kapitalizm, Signum, Kraków.

Bastiat F. [2003], Co widać i czego nie widać, Dextra, Lublin-Rzeszów. 
Boatright J. [2009], From Hired Hands to Co-owners: Compensation, Team-production and the Role of CEO, „Business Ethics Quarterly”, vol. 19, $\mathrm{nr} 4$.

Brejning J. [2012], Corporate Social Responsibility and the Welfare State. The Historical and Contemporary Role of CSR in the Mixed Economy of Welfare, University of Bristol, Ashgate.

Carroll A.B. [1983], Corporate Social Responsibility: Will Industry Respond to Cut-backs in Social Program Funding?, Vital Speeches of the Day, nr 49.

Carroll A.B. [1994], Social Issues in Management Research: Experts' Views, Analysis and Commentary, „Business \& Society”, vol. 33, nr 1.

Carroll A.B. [1999], Corporate Social Responsibility. Evolution of a Definitional Construct, „Business \& Society”, vol. 38, nr 3.

Chancellor E. [2001], Historia spekulacji finansowych, Wydawnictwo Literackie Muza, Warszawa.

Charan R., Freeman R.E. [1980], Planning for the Business Environment of the 1980s, „Journal of Business Strategy”, vol. 1, nr 2.

Cho Ch.H. i in. [2015], Organized Hypocrisy. Organizational Façades, and Sustainability Reporting, ,Accounting, Organizations and Society”, vol. 40, January.

la Cour A., Kromann J. [2011], Euphemisms and Hypocrisy in Corporate Philanthropy, „Business Ethics: A European Review”, vol. 20, nr 3.

Domańska E. [1986], Kapitalizm menedżerski, Państwowe Wydawnictwo Ekonomiczne, Warszawa.

Evan W.M., Freeman R.E. [1999], Teoria nowoczesnej korporacji oparta na koncepcji „udziałowców zewnętrznych”: kapitalizm kantowski [w:] Wprowadzenie do etyki biznesu, red. G.D. Chryssides, J.H. Kaler, PWN, Warszawa.

Firmy będa musiały raportować odpowiedzialność społeczna [2016], „Forbes”, http://csr. forbes.pl/obowiazki-raportowania-csr,artykuly,186749,1,1.html (dostęp: 6.06.2016).

Frederick W.C. [1987], Theories of Corporate Social Performance [w:] Business and Society: Dimensions of Conflict and Cooperation, red. S.P. Sethi, C. Falbe, Lexington Books.

Freeman R.E. [1983], Managing the Strategic Challenges in Telecommunications, „Columbia Journal of World Business”, vol. 18, nr 1.

Freeman R.E. [1984], Strategic Management: A Stakeholder Appproach, Pitman, Boston.

Freeman R.E., Harrison J.S., Cavalcanti Sá de Abreu M. [2015], Stakeholder Theory as an Ethical Approach to Effective Management: Applying the Theory to Multiple Contexts, ,Revista Brasileira de Gestão de Negócios. Review of Business Management”, vol. 17, nr 55.

Freeman R.E., McVea J. [2016], A Stakeholder Approach to Strategic Management, http:// papers.ssrn.com/paper.taf?abstract_id=263511 (dostęp: 6.06.2016).

Freeman R.E., Wicks A.C., Gilbert D.R. [1994], A Feminist Reinterpretation of the Stakeholder Concept, „Business Ethics Quarterly”, vol. 4, nr 4.

Friedman J. [2016], Milton Friedman Was Wrong about Corporate Social Responsibility, http://www.huffingtonpost.com/john-friedman/milton-friedman-was-wrong_b_3417866.html (dostęp: 6.06.2016).

Friedman M. [1997], Tyrania status quo, Panta, Sosnowiec.

Friedman M. [1999], Społeczna odpowiedzialność biznesu to zwiększanie zysków [w:] Wprowadzenie do etyki biznesu, red. G.D. Chryssides, J.H. Kaler, PWN, Warszawa.

Gadomski W. [2015], Teraz prezesi PiS, czyli ważna lojalność, http://wyborcza.biz/biznes/ 1,100897,19309510,teraz-prezesi-pis-czyli-wazna-lojalnosc.html\#ixzz3tlU0bHog (dostęp: 10.12.2015). 
Gruszecki T. [2002], Współczesne teorie przedsiębiorstwa, PWN, Warszawa.

Guczalska K. [2014a], Amartya Sen i ekonomia feministyczna, „Prakseologia”, nr 156.

Guczalska K. [2014b], CSR i Milton Friedman. Opowieść wigilijna i zły kapitalista, „Principia”, nr 59-60.

Hall P.A., Soskice D. [2001], An Introduction to Varieties of Capitalism [w:] Varieties of Capitalism: The Institutional Foundations of Comparative Advantage, red. P.A. Hall, D. Soskice, Oxford University Press.

Hendry J. [2001], Missing the Target: Normative Stakeholder Theory and the Corporate Governance Debate, „Business Ethics Quarterly” vol. 12, nr 1.

Holcombe R.G. [2014], http://mises.pl/wp-content/uploads/2014/01/Holcombe_Kapitalizm-kumoterski.pdf (dostęp: 5.12.2015).

Jensen M.C. [2001], Value Maximization, Stakeholder Theory, and the Corporate Objective Function, http://www.chinadinghui.com/doc/306.pdf.

Jones C., Parker M., ten Bos R. [2005], For Business Ethics, Routledge, London-New York.

Kant I. [2001], Uzasadnienie metafizyki moralności, przeł. M. Wartenberg, Antyk, Kęty.

Kant I. [2005], Idea powszechnej historii w aspekcie kosmopolitycznym, przeł. M. Żelazny, Antyk, Kęty.

Kant I. [2006], Metafizyczne podstawy nauki prawa, przeł. W. Galewicz, Antyk, Kęty.

Key S. [1999], Toward a New Theory of the Firm: a Critique of Stakeholder „Theory”, „Management Decision”, vol. 37, nr 4.

Kirkpatrick G. [2009], The Corporate Governance Lessons from the Financial Crisis, „Financial Market Trends”, vol. 1.

Klimczak B. [2012], Fuzje i przejęcia - analiza etyczna [w:] Biznes, etyka, odpowiedzialność, red. W. Gasparski, PWN, Warszawa.

Kowalik T. [2009], www.polskatransformacja.pl, Muza, Warszawa.

Marens R., Wicks A.C. [1999], Getting Real: Stakeholder Theory, Managerial Practice, and the General Irrelevance of Fiduciary Duties Owed to Shareholders, „Business Ethics Quarterly", vol. 9, nr 2.

Mises L. [2007], Ludzkie działanie. Traktat o ekonomii, Instytut Ludwiga von Misesa, Warszawa.

Moon J. [2002], Corporate Social Responsibility: An Overview [w:] The International Directory of Corporate Philanthropy, red. C. Hartley, Europa Publications, LondonNew York.

Nowak M. [2015], Koncepcja etyki pomiaru osiagnięć w kontekście teorii interesariuszy, Studia Ekonomiczne. Zeszyty Naukowe Uniwersytetu Ekonomicznego w Katowicach, nr 245.

Phillips R., Freeman R.E., Wicks A.C. [2003], What Stakeholder Theory Is Not, „Business Ethics Quarterly" vol. 13, nr 4.

Stanny D. [2010], CSR a obecny kryzys finansowy [w:] Moralny wymiar kryzysu ekonomicznego, red. J. Filek, Fundacja Biblioteki Uniwersytetu Ekonomicznego w Krakowie, Kraków.

Stanny D. [2015], Teoria interesariuszy wczesnego Freemana - nie tylko etyka, Fundacja Biblioteki Uniwersytetu Ekonomicznego w Krakowie, http://odpowiedzialnybiznes. pl/artykuly/teoria-interesariuszy-wczesnego-freemana-nie-tylko-etyka/ (dostęp: 5.12.2015). 
Sternberg E. [1997], The Defects of Stakeholder Theory, „Corporate Governance: An International Review", vol. 5, nr 1.

Sternberg E. [1998], Czysty biznes. Etyka biznesu w działaniu, PWN, Warszawa.

Stone C.D. [1997], Dlaczego spótki nie miałyby ponosić odpowiedzialności wobec społeczeństwa? [w:] Etyka biznesu, L.V. Ryan, J. Sójka, W drodze, Poznań.

Sundaram A.K., Inkpen A.C. [2004a], The Corporate Objective Revisited, „Organization Science", vol. 15, nr 3 .

Sundaram A.K., Inkpen A.C. [2004b], Stakeholder Theory and „The Corporate Objective Revisited”: A Reply, „Organization Science”, vol. 15, nr 3.

Szymaniec P. [2009], Problematyka własności w filozofii prawa Immanuela Kanta [w:] Własność - idea, instytucje, ochrona, Wrocław.

Tapek K. [2016], Corporate Social Responsibility w kontekście imperatywu kategorycznego Kanta, „Annales. Etyka w życiu gospodarczym”, vol. 19, nr 1.

Visser W. [2005], Revisiting Carroll's CSR Pyramid: An African Perspective [w:] Corporate Citizenship in a Development Perspective, red. E.R. Pedersen, M. Huniche, Copenhagen Business School Press, Copenhagen.

What Does Business Think about Corporate Social Responsibility? [2005], http://www. cpf.sk/files/files/VV\%20what\%20does\%20businnes\%20think\%20about\%20CSR.pdf (dostęp: 5.12.2015).

Wicks A.C., Gilbert D.R., Freeman R.E. [1994], A Feminist Reinterpretation of Stakeholder Concept, „Business Ethics Quarterly”, vol. 4, nr 4.

Żelazna-Blicharz A. [2013], Społeczna odpowiedzialność w procesie gospodarowania a zrównoważona produkcja i konsumpcja, Politechnika Lubelska, Lublin.

\section{Corporate Social Responsibility: Contradictions, Abuse of Ethics, and the Role of the Idea}

(Abstract)

The author posits that corporate social responsibility (CSR), in the narrow definition of the term, is not so much a positive idea that leads towards a better future, sustainable development, and sustainable economy, but a tool in the struggle for the right to manage a corporation; the politicisation of economy; and a way to camouflage activities which do not pursue noble ethical ideas but rather financial profit. The article presents arguments for the thesis that CSR, understood as an ideology used by corporate boards, has contributed to a crisis of corporate order. This is because, as a strategy or model of management, CSR has shaped certain relations between owners and shareholders, which have contributed to the weakness of shareholder supervision and control. The author opposes the too-ready idealisation of the idea of CSR, abuse of ethics (such as moral hazard or the bailout), and the theoretical inconsistency of Kantian capitalism. The cases analysed here highlight the fact that upper management is not held accountable for the consequences of poor decision-making and mistakes, which is inconsistent with the notion of CSR. The shortcomings of CSR are brought to light through the juxtaposition of Kantian capitalism, i.e. Robert E. Freeman's theory of stakeholders, with Milton Friedman's model of shareholder capitalism.

Keywords: CSR, business ethics, Kantian capitalism, theory of stakeholders, Robert Edward Freeman, Milton Friedman, Immanuel Kant, categorical imperative. 